\title{
A laparoszkópos és nyitott radikális hysterectomia összehasonlítása a méhnyakrák mútéti ellátásában
}

\author{
Lampé Rudolf dr. - Póka Róbert dr. \\ Debreceni Egyetem, Általános Orvostudományi Kar, Szülészeti és Nőgyógyászati Intézet, Debrecen
}

\begin{abstract}
Bevezetés: A méhnyakrák a nők egyik vezető haláloka a daganatos megbetegedések közül. A korai stádiumban felismert daganat mútéti ellátásának két leggyakrabban alkalmazott módja a laparoszkópos és a hasi út.

Célkitüzés: Célunk volt az idegkíméló totális laparoszkópos radikális hysterectomia és a hasi radikális hysterectomia intra- és posztoperatív eredményeinek összehasonlítása klinikánk anyagában.

Módszer: 2016 júniusától 2017 júniusáig 10 laparoszkópos és 11 hasi radikális méheltávolítást végeztünk korai stádiumú méhnyakrák miatt. Az eredményeket retrospektíve értékeltük.

Eredmények: Nem volt különbség a hasi és laparoszkópos mútétek között a mútéti időben, a vérvesztésben, az intraés posztoperatív szövődmények számában. Hasi mútéttel szignifikánsan több kismedencei nyirokcsomót távolítottunk el. A betegek hospitalizációjának ideje szignifikánsan rövidebb volt a laparoszkópos csoportban.

Következtetés: A totális laparoszkópos radikális hysterectomia mútéti eredményei a hasi radikális hysterectomia hasonló eredményeivel összehasonlíthatók, attól nem kedvezőtlenebbek. A laparoszkópos mútéttechnika előnyei miatt ennek a technikának a prioritása felmerül a korai stádiumú cervixcarcinoma mútéti kezelésében.

Orv Hetil. 2017; 158(36): 1403-1409.
\end{abstract}

Kulcsszavak: radikális hysterectomia, laparoszkópia, cervixcarcinoma

\section{Comparison of laparoscopic and open radical hysterectomies in the surgical treatment of cervical cancer}

Introduction: Cervical cancer is one of the most common causes of death among women with malignant tumours. The two most common ways of surgical technique of early stage cervical cancer is the laparoscopy and the laparotomy.

Aim: Our aim was to compare the intra- and postoperative results of total laparoscopic radical hysterectomy and abdominal radical hysterectomy.

Method: Ten nerve sparing laparoscopic and 11 abdominal radical hysterectomies were performed from June 2016 until June 2017 because of early stage cervical cancer. Results were analysed retrospectively.

Results: There was no significant difference between the two groups in the length of the operation, in blood loss and in intra- and postoperative complications. Significantly more lymph nodes were harvested by abdominal surgery and the length of hospitalisation was significantly shorter in the laparoscopy group.

Conclusion: Results of total laparoscopic radical hysterectomy are comparable and not worse than abdominal radical hysterectomy. Laparoscopic way may have a priority because of the general advantages of laparoscopic surgery in the surgical treatment of early stage cervical cancer.

Keywords: radical hysterectomy, laparoscopy, cervical cancer

Lampé R, Póka R. [Comparison of laparoscopic and open radical hysterectomies in the surgical treatment of cervical cancer]. Orv Hetil. 2017; 158(36): 1403-1409.

(Beérkezett: 2017. június 20.; elfogadva: 2017. július 19.) 


\section{Rövidítések}

$\mathrm{ARH}=$ abdominalis radikális hysterectomia; $\mathrm{BMI}=($ body mass index) testtömegindex; IP = infundibulopelvicum; $\mathrm{MR}=$ (magnetic resonance) mágneses rezonancia; LRH = laparoszkópos radikális hysterectomia; TLRH = totális laparoszkópos radikális hysterectomia

A méhnyakrák világszerte a második leggyakoribb oka a daganatos betegségek miatti halálozásnak a nők körében, ez hozzávetőleg 266000 halálesetet jelen évente [1, 2]. A daganatos betegek korai stádiumban operálhatóak, előrehaladott stádiumban a mütét nem jön szóba. A fejlődő országokban a méhnyakrákos esetek több mint 70\%-a előrehaladott állapotban kerül felismerésre [3]. A betegség incidenciájának két csúcsa van, 29-30, illetve 60-64 éves kor között [4].

A korai stádiumú méhnyakrák (FIGO-stádium IA2IIB) mütéti ellátása a radikális méheltávolítás, ami az uterus, parametrium és a hüvely felső egyharmadának eltávolítását jelenti. A mütét részeként kétoldali kismedencei lymphadenectomiát is végzünk. A radikális méheltávolítás kiterjesztésének meghatározására korábban Piver 1974-es klasszifikációja volt használatban, azonban ennek hátrányai az egyértelmú anatómiai határok hiánya és a nem egységes anatómiai definíciók voltak, valamint a nem egységes nómenklatúra [5]. Ennek kiküszöbölésére hozták létre a Querleu és Morrow által leírt beosztást, amely egyértelmű anatómiai határokkal, egységes nevezéktannal írja le a radikális hysterectomia kiterjesztésének típusait [6].

A radikális méheltávolítás laparoszkópos technikáját 1992-ben Canis és Nezhat írta le először, azonban ezek a mütétek még kifejezetten időigényesek és kérdéses radikalitásúak voltak $[7,8]$. A technikai fejlődéssel párhuzamosan azonban mind népszerúbbekké, eredményeik pedig egyre meggyőzőbbé váltak. A radikális hysterectomia posztoperatív morbiditása azonban még így is jelentős volt a kismedencei autonóm idegek sérülése miatt [9, 10]. A kismedencei autonóm idegrendszer integritása nélkülözhetetlen a kismedencei szervek normális múködéséhez. A paraszimpatikus idegek sérülése hiperkontraktilis vagy akontraktilis húgyhólyagot eredményez, a vizelési inger érzésének csökkenésével. A szimpatikus idegek sérülése hólyagnyak-inkompetenciát és vizeletinkontinenciát, valamint colorectalis motilitási rendellenességeket okozhat. Az autonóm idegrendszer sérülése a megváltozott vascularis funkción keresztül szexuális diszfunkcióhoz is vezethet [11-13].

A nőgyógyászati onkológiai mútéttechnika további fejlődésének köszönhetően kidolgozásra került az idegkímélő radikális méheltávolítás, ami a laparoszkópos mütétek során, a nagyított képnek köszönhetően, jól alkalmazható. A kismedencei autonóm idegellátásban részt vesznek a nervus hypogastricusok, amik az ureterekkel parallel futnak, azoktól nagyjából $2 \mathrm{~cm}$-re mediodorsalisan, és fóként szimpatikus rostokat tartalmaznak. A ner- vus hypogastricusok caudalisabban, az S2-S4 gyökökből eredő, elsősorban paraszimpatikus kismedencei splachnicus idegrostokkal fuzionálnak, létrehozva a plexus hypogastricus inferiort, ami a rectum anterolateralis, a hüvely lateralis és a húgyhólyag basalis részeit látja el [14]. Mütéttechnikailag a leírt idegek preparálásával és látótérbe hozásával, valamint a parametrium caudalis határának (mély uterinalis véna) kijelölésével az idegek sérülése elkerülhető.

Célunk volt a hasi és laparoszkópos radikális méheltávolítás és kismedencei lymphadenectomia kivitelezhetőségének, kezdeti eredményeinek és morbiditásának öszszehasonlítása a korai stádiumú méhnyakrák mútéti kezelésében.

\section{Módszer}

2016 júniusa és 2017 júniusa között 10 betegnél végeztünk idegkímélő totális laparoszkópos radikális hysterectomiát (TLRH) és kétoldali kismedencei szisztematikus lymphadenectomiát, valamint 11 betegnél abdominalis radikális hysterectomiát $(\mathrm{ARH})$ és kismedencei lymphadenectomiát a Debreceni Egyetem Szülészeti és Nőgyógyászati Klinikáján FIGO IAl-IIB stádiumú méhnyakrák miatt. A mútétekre az intézeti onkológiai bizottság jóváhagyását követően került sor, a betegek tájékoztatását (kezelési lehetőségek, neoadjuváns kemoterápia, mütéti szövődmények, beleértve a laparotomiára történő konverziót is) követően, a tájékozott beleegyezésük után.

A cervixcarcinoma patológiai diagnózisa conisatióval vagy >Ibl esetekben cervixbiopsziával történt meg. A preoperatív radiológiai stádiumbeosztás alapja minden esetben mágneses rezonanciás (MR) vizsgálat volt. Ezt kiegészítette a fizikális vizsgálaton alapuló klinikai stádiumbeosztás. A FIGO IIB-be sorolt betegek három ciklusban platinaalapú neoadjuváns kemoterápiában részesültek (bleomycin-ifosfamid-cisplatin protokoll szerint), majd újabb MR-vizsgálat készült, amely minden esetben a daganat regresszióját írta le. Minden beteg QuerleuMorrow szerinti Cl kiterjesztésű radikális méheltávolításon esett át. A TLRH és ARH közötti döntés preoperatíve született az operáló orvos jártasságától, az orvos és a beteg preferenciájától, valamint a beteg általános állapotától függően. A mütét során a betegek antibiotikumprofilaxisban (cefazolin 2 g intravénásan) és perioperatív alacsony molekulasúlyú heparinkezelésben részesültek. A műtéteket generalizált narkózisban, endotrachealis intubációval végeztük. A műtéten átesettek klinikai és perioperatív adatait az 1 . táblázat mutatja.

Az ARH-mútétek esetében a klinikánkon rutinszerüen alkalmazott eljárást folytattuk. A TLRH-mútéteket standardizált mútéttechnika alapján végeztük el [15]. Uterusmozgatót, illetve hüvelyi obturatort alkalmaztunk, de azt a nyakcsatornába nem rögzítettük. A 10 mm-es optikai trokárt a köldökön keresztül vezettük a hasüregbe, direkt behatolással, majd három $5 \mathrm{~mm}$-es behatoláson 
1. táblázat |A betegek klinikai adatai és perioperatív műtéti eredmények

\begin{tabular}{llll}
\hline & $\begin{array}{l}\text { Laparoszkópia } \\
(\mathrm{n}=10)\end{array}$ & $\begin{array}{l}\text { Laparotomia } \\
(\mathrm{n}=11)\end{array}$ & p-érték \\
\hline Kor $(\mathrm{év})$ & $47,6 \pm 11,2$ & $51,8 \pm 10,8$ & $\mathrm{NS}$ \\
BMI $\left(\mathrm{kg} / \mathrm{m}^{2}\right)$ & $24,1 \pm 2,5$ & $27,2 \pm 5,2$ & $\mathrm{NS}$ \\
Mútéti idő (perc) & $165 \pm 28,1$ & $165,4 \pm 169,9$ & $\mathrm{NS}$ \\
$\begin{array}{l}\text { Hemoglobincsökkenés } \\
\text { (g/L) }\end{array}$ & $20,3 \pm 11,7$ & $24,9 \pm 13,1$ & $\mathrm{NS}$ \\
$\begin{array}{l}\text { Hematokritcsökkenés } \\
\text { Transzfúzióigény (beteg) * }\end{array}$ & $0,08 \pm 0,04$ & $0,06 \pm 0,04$ & $\mathrm{NS}$ \\
\begin{tabular}{l} 
Hospitalizáció (nap) \\
\hline
\end{tabular} & $5,4 \pm 2,17$ & $10,4 \pm 3,5$ & $\mathrm{NA}$ \\
\hline
\end{tabular}

Az értékek átlagot jelölnek \pm szórás.

*Az értékek esetszámot jelölnek.

$\mathrm{BMI}=($ body mass index $)$ testtömegindex $; \mathrm{NA}=$ nincs adat NS = nem szignifikáns

keresztül vezettük be az eszközöket (bipoláris koagulálóeszköz, ultrahangos koaguláló-vágó eszköz és atraumatikus fogó). Ezek elhelyezése a középvonalban, 3 cmrel a symphisis felett, valamint bal és jobb oldalon, $2 \mathrm{~cm}$-rel a spina iliaca anterior superior felett történt. $\mathrm{Az}$ intraabdominalis nyomás 13-15 Hgmm volt, 12-15-os Trendelenburg-pozícióban. A mútét a kismedencei szervek és a felhas megfigyelésével kezdődött. Ezt követően a kismedencéből eltávolítottuk a vékonybeleket, a szigmabél bal oldali, fiziológiás medencefali kitapadását szükség esetén oldottuk. A mútétet a peritoneum megnyitásával kezdtük a ligamentum infundibulopelvicum (IP) és az ureter között. Innen a peritoneumot eleinte az ureterek felett, majd a rectum irányába hasítottuk, és a Denonvillier-fascia két rétegét szeparálva a rectumot letoltuk a hátsó hüvelyfalról. Mindkét oldalon koaguláltuk és átvágtuk a ligamentum rotundumot, majd a peritoneumot meghasítottuk az IP-szalaggal párhuzamosan. Látótérbe hoztuk az arteria és vena iliaca externát, az arteria hypogastricát és az uretert. Kipreparáltuk a paravesicalis és pararectalis tereket, ezzel együtt az arteria uterina eredését, amit koaguláltunk és átvágtunk. Az uretert felszabadítottuk a ligamentum latum hátsó lemezétől, egészen az uretercsatornáig, és a nervus hypogastricus megkímélése mellett a hátsó parametriumot átvágtuk. A paraszimpatikus rostokat szállító nn. splachnici a sacralis ideggyökökből erednek, és a tőlük medialisan elhelyezkedő nervus hypogastricussal fuzionálnak, így ezek sérülésére a nervus hypogastricusok látótérbe hozása, valamint a mély uterinalis vénánál mélyebb rétegek preparálásának elkerülése esetén nem kell számítanunk. Ezt követően meghasítottuk a mellső áthajlást és a hólyagot a cervixről és a hüvely felső harmadáról élesen mobilizáltuk a vesicovaginalis fascia fölött. $\mathrm{Az}$ uretercsatornát az ureter lateralizálásával megnyitottuk, ezzel az uretert teljesen mobilizáltuk. Ezt követően

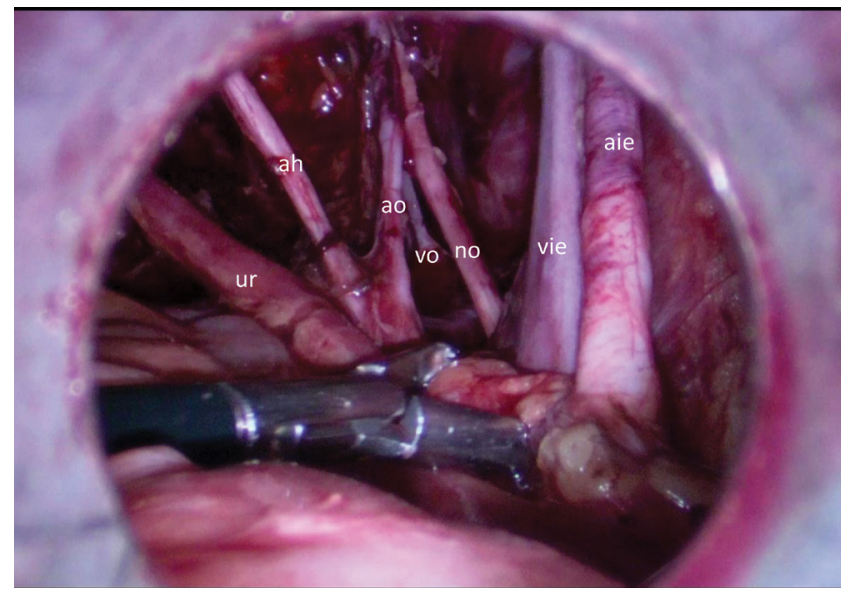

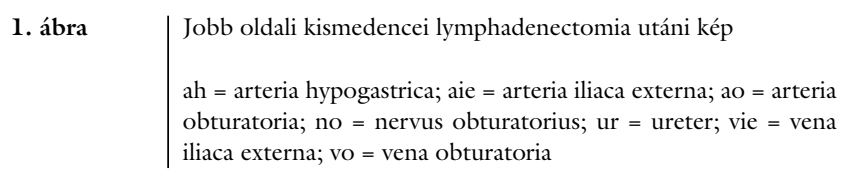

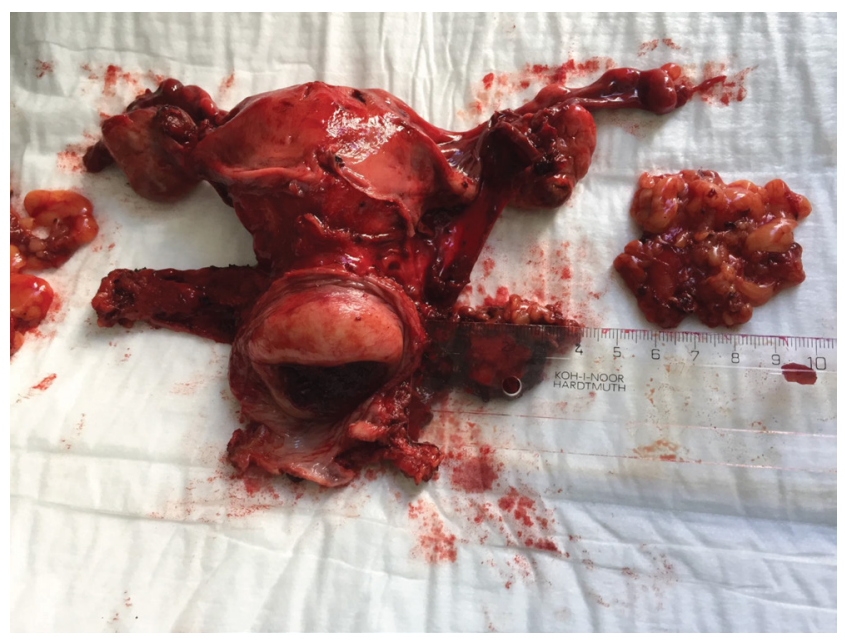

2. ábra

Uterus függelékekkel, parametriummal, hüvelymandzsettával, valamint az eltávolított nyirokszövettel

a lateralis parametriumot $2-3 \mathrm{~cm}$-rel lateralisan a cervixtől és a mellső parametriumot a húgyhólyag felszínén átvágtuk. A hüvely boltozatától 2-3 $\mathrm{cm}$-rel caudalisan a hüvelyfalat monopoláris eszközzel átvágtuk. Mindkét oldalon koagulálást követően átvágtuk az IP-szalagokat. Az uterust a hüvelyen keresztül távolítottuk el.

Mindkét oldalon szisztematikus kismedencei lymphadenectomiát végeztünk (1. ábra). Ennek során feltártuk a lateralis paravesicalis teret, és az arteria iliaca communistól a vena iliaca circumflexa profundáig a parailiacalis, valamint az obturator üregi nyirokcsomóláncot lehetőség szerint egy blokkban eltávolítottuk az obturator ideg és érképletek megkímélésével. Az ilio-obturator régió minden esetben nyirokszövetmentes lett. A hüvelycsonkot nyolcas öltésekkel zártuk, felöltve a vesicovaginalis fasciát és a sacrouterin szalagokat is, extracorporalis csomózási technikával, 1-es felszívódó fonállal. A hasüreget 
drenáltuk, amit a mútétet követő 24 óra múlva távolítottunk el.

A folytonos változók statisztikai elemzéséhez Studentféle kétmintás t-próbát használtunk, a p<0,05 értéket tekintettük szignifikánsnak.

\section{Eredmények}

A betegek klinikai adatai az 1. táblázatban láthatóak. Az átlagéletkor és a testtömegindex (BMI) hasonló volt a két vizsgálati csoportban. Nem volt szignifikáns eltérés a mütét hosszában a csoportok közt. A vérveszteség mérésére a hemoglobin- és hematokritértékeket vettük alapul. A műtét előtt, illetve 24 órával a mütét után vettünk vért a betegektől, majd kiszámoltuk azok különbségét. Eredményeink szerint nem volt szignifikáns eltérés a hemoglobin- és hematokrit különbségekben a két vizsgálati csoport között. Két beteg részesült transzfúzióban a mütétet követően az ARH-csoportból. Intraoperatív transzfúzióra nem volt szükség egyik csoportban sem. Szignifikáns eltérést a hospitalizáció hosszában találtunk, ami kevesebbnek bizonyult a TLRH-csoportban. Reoperációra vagy TLRH esetén ARH-ra konvertálni egyik esetben sem volt szükség.

\section{2. táblázat |A mútétek jellemzői}

\begin{tabular}{|c|c|c|c|}
\hline & $\begin{array}{l}\text { Laparoszkópia } \\
(\mathrm{n}=10)\end{array}$ & $\begin{array}{l}\text { Laparotomia } \\
(\mathrm{n}=11)\end{array}$ & p-érték \\
\hline \multicolumn{4}{|l|}{ Gradus } \\
\hline 1 & 2 & 2 & NA \\
\hline 2 & 6 & 6 & NA \\
\hline 3 & 2 & 3 & NA \\
\hline \multicolumn{4}{|l|}{ Stádium } \\
\hline IAl & 2 & 2 & NA \\
\hline IB 1 & 3 & 6 & NA \\
\hline $\mathrm{IIB}$ & 5 & 3 & NA \\
\hline \multicolumn{4}{|l|}{ Szövettan } \\
\hline Adenocarcinoma & 3 & 2 & NA \\
\hline Squamosus & 7 & 9 & NA \\
\hline $\begin{array}{l}\text { Eltávolított nyirokcsomók } \\
\text { száma* }\end{array}$ & $16,4 \pm 2,72$ & $21,09 \pm 5,6$ & $<0,05$ \\
\hline Parametrium mérete $(\mathrm{cm})^{*}$ & $3,8 \pm 0,7$ & NA & NA \\
\hline $\begin{array}{l}\text { Hüvelymandzsetta mérete } \\
(\mathrm{cm})^{\star}\end{array}$ & $2,0 \pm 0,4$ & NA & NA \\
\hline Intraoperatív komplikáció & 1 & 2 & NS \\
\hline Posztoperatív komplikáció & 0 & 1 & NS \\
\hline
\end{tabular}

Az értékek esetszámot jelölnek.

*Az értékek átlagot jelölnek \pm szórás.

$\mathrm{NA}=$ nincs adat; $\mathrm{NS}=$ nem szignifikáns
A mütétek eredményeit a 2. táblázat mutatja. Nem volt lényeges különbség a két csoportban a tumor differenciáltsági fokában, a sebészeti stádiumában, hisztológiai típusában. Az eltávolított nyirokcsomók száma az ARH-csoportban szignifikánsan több volt. A rutin patológiai feldolgozásunk nem tartalmazza a parametrium és a hüvelymandzsetta méretének leírását. A retrospektív adatgyújtés miatt az ARH-csoportban ezek a méretek nem ismertek, mivel a mútéti preparátumról nem készítettünk fotódokumentációt. TLRH esetén a mütét rögzítése és a mütéti preparátum fotódokumentációja részét képezi a mútéti protokollunknak, így az említett eredmények rendelkezésünkre állnak (2. ábra).

TLRH során posztoperatív komplikáció nem volt, egy esetben történt intraoperatív komplikáció. A húgyhólyag preparálása során körülbelül 1,5 cm-es áthatoló hólyagsérülés keletkezett, amit laparoszkópos úton csomós öltésekkel zártunk. Az alkalmazott próba során a húgyhólyag varratsora jól tartott. Az állandó katétert öt nap múlva távolítottuk el, a beteg komplikációmentesen gyógyult.

Az ARH-mútétek kapcsán két esetben volt intraoperatív komplikáció. Az egyik a húgyhólyag áthatoló sérülése volt, amelynek ellátása a TLRH-nál ismertetett módhoz hasonló volt. A másik intraoperatív komplikáció a vena iliaca externa sérülése volt, amit öltéssel szövődménymentesen elláttunk. Egy esetben volt posztoperatív komplikáció, ami a hasi seb felületes szétválása volt a varratok eltávolítását követően, a hasfali fascia intakt maradt. Itt resutura történt. Hólyagkatéter-visszahelyezést vagy önkatéterezést igénylő hólyaghűdés a vizsgált esetek között nem fordult elő.

\section{Megbeszélés}

Bár a korai stádiumú cervixcarcinoma sebészeti ellátásának „gold standardja” napjainkban is az ARH kétoldali kismedencei lymphadenectomiával, néhány centrumban a TLRH felváltja, mint elsődlegesen választandó mútéti eljárás. A kezdeti, kérdéses radikalitású, hosszadalmas mútétek a technikai fejlődés és a gyakorlati ismeretek gyarapodásának köszönhetően mára elfogadható, sőt szakirodalmi adatok szerint is több szempontból kedvezőbb eredménnyel járó beavatkozások, mint az ARH.

Egy 2015-ös metaanalízis, ami 12 klinikai vizsgálat eredményeit összegezi, a TRLH-t megfelelő technikának tartja a cervixcarcinoma mútéti ellátására, jobb rövid távú kimenetellel, mint az ARH [16]. Nincs különbség az onkológiai kimenetelben és az ötéves túlélésben a két módszer között. A műtéti idő rövidebb a nyitott műtéteknél a laparoszkópos mútétekhez képest $(240 \pm 85,1$ vs. $251,5 \pm 78,3$ perc). A mütét alatti vérveszteség a laparoszkópos csoportban lényegesen kevesebb $(258,4 \pm$ $311,1 \mathrm{ml})$ az ARH-csoporttal összehasonlítva $(524,1 \pm$ $650,8 \mathrm{ml}$ ). A hospitalizáció a TLRH-csoportban átlagosan 3,22 nappal volt rövidebb. Nem volt különbség az eltávolított nyirokcsomók számában (LRH: 17-29,7; 
3. táblázat | Egyes közlemények eredményeinek összehasonlítása

\begin{tabular}{|c|c|c|c|c|c|c|c|}
\hline Szerzők, év & Betegszám (fó) & Mütéti idő (perc) & $\begin{array}{l}\text { Nyirokcsomók } \\
\text { száma }\end{array}$ & $\begin{array}{l}\text { Intraoperatív } \\
\text { komplikáció }\end{array}$ & $\begin{array}{l}\text { Posztoperatív } \\
\text { komplikáció }\end{array}$ & $\begin{array}{l}\text { Hospitalizáció } \\
\text { (nap) }\end{array}$ & Vérvesztés \\
\hline Malzoni, 2009 & $65 / 62$ & $196 / 152$ & $23 / 25$ & $1 / 1$ & $1 / 0$ & $4 / 7$ & $5 / 10 \mathrm{~g} / 1$ \\
\hline Hong, 2012* & 118 & 270 & 26 & 16 & 8 & 7 & $17 \mathrm{~g} / 1$ \\
\hline Nam, 2012 & $263 / 263$ & $247 / 247$ & $34 / 31$ & $18 / 15$ & $24 / 55$ & $13 / 20$ & $21 / 23 \mathrm{~g} / 1$ \\
\hline Lim, 2013 & $18 / 30$ & $268 / 240$ & $26 / 22$ & $1 / 0$ & $2 / 4$ & $5 / 6$ & $300 / 500 \mathrm{ml}$ \\
\hline Xiao, 2015 & $106 / 48$ & $271 / 310$ & $20 / 24$ & $4 / 4$ & $26 / 25$ & NA & $233 / 798 \mathrm{ml}$ \\
\hline $\begin{array}{l}\text { Saját } \\
\text { eredményeink }\end{array}$ & $10 / 11$ & $165 / 165$ & $16 / 21$ & $1 / 2$ & $0 / 1$ & $5 / 10$ & $20 / 25 \mathrm{~g} / 1$ \\
\hline
\end{tabular}

Az értékek feltüntetése: laparoszkópia/laparotomia.

*Az értékek feltüntetése: laparoszkópia.

$\mathrm{NA}=$ nincs adat

ARH: 18,8-34,6). Hasonlónak bizonyult az intraoperatív komplikációk száma is. A leggyakoribb a húgyhólyag sérülése (LRH: 3\%, ARH: 2,2\%), ezt követi az ureter sérülése (LRH: 1,2\%, ARH: 0,8\%) és a bélsérülés (LRH és ARH: 0,3\%). A posztoperatív komplikációk közül a sebfertőzés, a lázas szövődmény, a seb dehiszcenciája gyakrabban fordult elő az ARH-csoportban, de nem volt különbség a vizeletelvezető rendszer fertőzéseiben, a kismedencei tályog kialakulásában, a posztoperatív vérzésben és az ureterstrictura vagy -fistula kialakulásában.

Az elmúlt évek, valamint a legnagyobb esetszámú TLRH-val kapcsolatos közlemények összehasonlítható eredményeit a 3. táblázat mutatja be [17-21]. Malzoni és mtsai szerint a laparoszkópos csoportban szignifikánsan alacsonyabb intraoperatív vérveszteség és hospitalizáció, valamint hosszabb mútéti idő volt az ARH-csoporthoz képest. Kevesebb volt a laparoszkóposan eltávolított nyirokcsomók száma, de nem volt eltérés az intra- és posztoperatív komplikációk számában. Onkológiai szempontból lényeges kiemelni, hogy a két mütéti technika között nem volt eltérés a recidíva előfordulásában [17]. Hong és mtsai saját TLRH-mütéti eredményeiket nem hasonlították össze ARH-csoporttal [18]. Egy másik, az egyik legnagyobb betegszámú összehasonlító elemzésben a laparoszkópos csoportban nem volt a két csoport között különbség a vérvesztésben, a TLRH esetén a posztoperatív komplikáció kevesebb volt, és szignifikánsan több volt az eltávolított nyirokcsomók száma. Nem volt különbség a mütéti idő és az intraoperatív komplikációk tekintetében. Megemlítendő, hogy a laparoszkópos csoport hospitalizációs ideje szignifikánsan alacsonyabb volt, de mindkét csoportban nehezen magyarázhatóan hosszú volt ez az időszak. Sem a progreszsziómentes túlélésben, sem a teljes túlélésben nem volt különbség a két csoport között az ötéves nyomon követés során [19]. Lim és mtsai közleményében is kevesebbnek adódott az intraoperatív vérveszteség TLRH során, mint ARH kapcsán, de nem volt eltérés a mütéti időben, a vérvesztésben, a hospitalizációban, az eltávolított nyirokcsomók számában, valamint az intra- és posztoperatív komplikációk gyakoriságában [20]. Xiao és mtsai eredményeiben a TLRH-csoportban kevesebb volt a vérveszteség és a posztoperatív komplikáció, továbbá az ARHcsoportban több nyirokcsomót távolítottak el. A mütéti időben nem volt különbség [21].

Saját eredményeink szerint nem volt különbség a mütéti időben, de kiemelendő a TLRH-mútétek jelentősen kisebb arányú szórása az ARH-mútétekhez képest, aminek magyarázata lehet az egységes technikai kivitelezés, azaz a standardizált mútéttechnika. Az eredményekből kitûnik, hogy a mi laparoszkópos mütéti időnk a többi, 3. táblázatban szereplő szerzők hasonló eredményeihez képest jelentősen rövidebb. Ennek magyarázatát a mütéttechnikai kivitelezésben látjuk. Az általunk használt módszer a Puntambekar és mtsai által bemutatott standardizált technika, amelynek átlagos mütéti ideje 92 perc [15]. Összehasonlítva eredményeinket a 3. táblázatban feltüntetett szerzők eredményeivel a mütéti idő elfogadható hosszúságú, az intra- és posztoperatív komplikációk száma, valamint a hospitalizáció ideje a többi szerzó eredményéhez hasonló. Bizonyos eredmények azonban nehezen összevethetők egymással, jelentős eltéréseket tartalmazhatnak az egyes munkacsoportok között. Minderre magyarázat lehet a nem egységes technikai kivitelezés, nem egységes nómenklatúra, az operáló orvosok nem egységes szakmai, technikai felkészültsége, valamint az eltérő szokások a posztoperatív gondozás tekintetében. Széles spektrumon mozog többek között a mütét alatti vérvesztés mennyiségi mutatója. A mütét alatti vérvesztés ml-ben való becslése csak közelítő adat lehet, nem tudjuk megítélni a vér hígulását a mosófolyadékkal, valamint vérvesztés történik a mútét után is. Leggyakrabban a pre- és posztoperatív hemoglobincsökkenést adják meg a szerzők, de a hematokritváltozás nélkül ez nehezen értelmezhető. Ismert, hogy pre- és posztoperatív intenzív kezelés részeként akár jelentős mennyiségü intravénás folyadékpótlás is történhet a helyi szokásoktól függően, ez jelenleg is vitatott területe az aneszteziológiának, mivel a legújabb ajánlások inkább a mútét alatti folyadékpótlás megszorítását javasolják. 
A mütét alatti vérvesztés legérzékenyebb indikátora az intra- vagy posztoperatív transzfúziós igény, de ezt is befolyásolja a mütét előtti haemostatus. Saját eredményeinkben két betegnél kellett transzfúziót adni az ARHcsoportban, a TLRH-csoportban nem volt rá szükség. A transzfúzióban részesülő két beteg hemoglobinszintje alacsonyabb, de még transzfúziót nem igénylő volt a mưtét előtt is. A mütétet követő hemoglobin- és hematokritcsökkenés náluk sem tért el jelentősen a többi vizsgált betegétől. A hemoglobin- és hematokritcsökkenésben nem volt szignifikáns különbség az ARH- és TLRH-csoportok közt, illetve a más munkacsoportok eredményeihez lényegében hasonló mértékű volt. Hasonlóan nehezen értékelhető az eltávolított nyirokcsomók számával kapcsolatos adat. Ez nagyban múlik a mintát értékelő patológuson, illetve az általa használt módszeren is. A méhnyakrák kapcsán nincs meghatározva a minimálisan eltávolítandó nyirokcsomók száma, azonban általánosan elfogadottnak a több mint 10 nyirokcsomót tekinthetjük. A mi eredményeink ennek a kívánalomnak megfelelnek. Megjegyzendő, hogy nincs egységes szakirodalmi adat arról, hogy melyik mütéti módszerrel távolítható el több nyirokcsomó. Erre példa az összehasonlító 3. táblázatban szereplő szerzők eredményei, amelyek közül két esetben a laparoszkóppal, míg két esetben a laparotomiával végzett mütétek esetén volt nagyobb az eltávolított nyirokcsomók száma.

A vizsgálatunk kritikai elemzése kapcsán megemlítendő az alacsony esetszám mindkét csoportban és a hosszú távú nyomon követés, valamint az onkológiai kimenetel elemzésének hiánya. Mégis fontosnak tartjuk az adatok ilyen formában történő értékelését, és eredményeink közzétételét. Eseteink patológiai adatai arra engednek következtetni, hogy kellő részletességű kivizsgálás és betegválogatás mellett az endoszkópos technológiával végzett kiterjesztett mútét adekvát diagnosztikus információt biztosít a posztoperatív kezelési, illetve gondozási terv felállításához.

\section{Következtetés}

Elmondható, hogy a korai stádiumú méhnyakrák kezelésében a laparoszkópos radikális méheltávolítás kismedencei lymphadenectomiával gyakorlott kezekben egy hatékony, biztonságos mütéttechnika, amelynek eredményei nem rosszabbak a hasi radikális méheltávolítás eredményeinél. A laparoszkópia egyértelmű előnyei miatt (kisebb mütéti heg és posztoperatív fájdalom, gyorsabb felépülés) felmerül ennek a technikának a prioritása. Egységes technikai kivitelezés és nómenklatúra, valamint randomizált prospektív vizsgálatok segítenének a módszer objektív értékelésében, az eredmények összehasonlításában.
Anyagi támogatás: A közlemény megírásához anyagi támogatásban egyik szerző sem részesült.

Szerzői munkamegosztás: L. R.: A közlemény megírása, irodalomkutatás, mütétek elvégzése, a vizsgálat koordinációja. P. R.: A vizsgálat ellenőrzése, a műtétek elvégzése. A cikk végleges változatát mindkét szerző elolvasta és jóváhagyta.

Érdekeltségek: A szerzőknek nincsenek érdekeltségeik.

\section{Irodalom}

[1] Poveda A, Martin AG. Multimodality treatment in locoregional gynecological cancer: cervical cancer treatment update. Ann Oncol. 2008; 19: 70-76.

[2] Ferlay JS, Ervik M, Dikshit R, et al. GLOBOCAN 2012 vl.0, Cancer incidence and mortality worldwide: IARC Cancer Base No. 11. Available from: http://globocan.iarc.fr [accessed: June 15, 2017].

[3] Ferlay J, Shin HR, Bray F, et al. Estimates of worldwide burden of cancer in 2008: GLOBOCAN 2008. Int J Cancer 2010; 127: 2893-2917.

[4] Jemal A, Siegel R, Ward E, et al. Cancer statistics 2006. CA Cancer J Clin. 2006; 56: 106-130.

[5] Piver MS, Rutledge F, Smith JP. Five classes of extended hysterectomy for women with cervical cancer. Obstet Gynecol. 1974; 44: 265-272.

[6] Querleu D, Morrow CP. Classification of radical hysterectomy. Lancet Oncol. 2008; 9: 297-303.

[7] Canis M, Mage G, Wattiez A, et al. Does endoscopic surgery have a role in radical surgery of cancer of the cervix uteri? J Gynecol Obstet Biol Reprod. 1990; 19: 921.

[8] Nezhat CR, Burrell MO, Nezhat FR, et al. Laparoscopic radical hysterectomy with paraaortic and pelvic node dissection. Am J Obstet Gynecol. 1992; 166: 864-865.

[9] Bergmark K, Avall-Lundqvist E, Dickman PW, et al. Vaginal changes and sexuality in women with a history of cervical cancer. N Engl J Med. 1999; 340: 1383-1389.

[10] Zullo MA, Manci N, Angioli R, et al. Vesical dysfunctions after radical hysterectomy for cervical cancer: a critical review. Crit Rev Oncol Hematol. 2003; 48: 287-293.

[11] Yalla SV, Andriole GL. Vesicourethral dysfunction following pelvic visceral ablative surgery. J Urol. 1984; 132: 503-509.

[12] Smith AN, Varma JS, Binnie NR, et al. Disordered colorectal motility following hysterectomy. Br J Surg. 1990; 77: 13611366.

[13] Brindley GS. The actions of parasympathetic and sympathetic nerves in human micturition, erection and seminal emission, and their restoration in paraplegic patients by implanted electrical stimulators. Proc R Soc Lond B Biol Sci. 1988; 235: 111-120.

[14] Maas CP, de Ruiter MC, Kenter GG, et al. The inferior hypogastric plexus in gynecologic surgery. J Gynecol Tech. 1999; 5: 5562.

[15] Puntambekar SP, Palep RJ, Puntambekar SS, et al. Laparoscopic total radical hysterectomy by the Pune technique: our experience of 248 cases. J Minim Invasive Gynecol. 2007; 14: 682-689.

[16] Wang YZ, Deng L, Xu HC, et al. Laparoscopy versus laparotomy for the management of early stage cervical cancer. BMC Cancer 2015; 15: 928 .

[17] Malzoni M, Tinelli R, Cosentino F, et al. Total laparoscopic radical hysterectomy versus abdominal radical hysterectomy with 
lymphadenectomy in patients with early cervical cancer: our experience. Ann Surg Oncol. 2009; 16: 1316-1323.

[18] Hong JH, Choi JS, Lee JH, et al. Can laparoscopic radical hysterectomy be a standard surgical modality in stage IA2-IIA cervical cancer? Gynecol Oncol. 2012; 127: 102-106.

[19] Nam JH, Park JY, Kim DY, et al. Laparoscopic versus open radical hysterectomy in early-stage cervical cancer: long-term survival outcomes in a matched cohort study. Ann Oncol. 2012; 23: 903-911.

[20] Lim YK, Chia YN, Yam KL. Total laparoscopic Wertheim's radical hysterectomy versus Wertheim's radical abdominal hysterec- tomy in the management of stage I cervical cancer in Singapore: a pilot study. Singapore Med J. 2013; 54: 683-688.

[21] Xiao M, Zhang Z. Total laparoscopic versus laparotomic radical hysterectomy and lymphadenectomy in cervical cancer: An observational study of 13-year experience. Medicine (Baltimore) 2015; 94: el264.

(Lampé Rudolf dr., Debrecen, Nagyerdei krt. 98., 4032 e-mail: rudolflampe@msn.com)

"Aspera perpessu fiunt iucunda relatu."

(Mit türnöd kín volt, már szinte öröm, ha meséled.)

\section{A rendezvények és kongresszusok híranyagának leadása}

a lap megjelenése előtt legalább 40 nappal lehetséges, a 6 hetes nyomdai átfutás miatt.

Kérjük megrendelőink szíves megértését.

A híranyagokat a következő címre kérjük:

Orvosi Hetilap titkársága: edit.budai@akademiai.hu

Akadémiai Kiadó Zrt. 